1 Department of Operative Dentistry, Endodontics, and Dental Materials, University of São Paulo, Bauru, Brazil.
Corresponding author: Mariana Maciel Batista Borges Department of Operative Dentistry, Endodontics, and Dental Materials, University of São Paulo, Bauru, Brazil.

mmbborges@usp.br

Editor: Dr Altair A. Del Bel Cury

Received: November 16, 2021

Accepted: June 04, 2021

\section{Physicochemical properties and antimicrobial activity of calcium hydroxide pastes in association with other compounds}

\author{
Mariana Maciel Batista Borges $1, \star$ (D), Mayara Conde \\ Frank $^{1}$ (D), Rafaela Fernandes Zancan ${ }^{1}$ (D), Talita \\ Tartari $^{1}$ (D), Rodrigo Ricci Vivan' ${ }^{10}$, Marco Antonio \\ Hungaro Duarte ${ }^{1}$ (D)
}

Aim: This study aimed to evaluate the $\mathrm{pH}, \mathrm{Ca}^{2+}$ release, solubility, and antimicrobial activity of calcium hydroxide $\left(\mathrm{Ca}(\mathrm{OH})_{2}\right)$ pastes in association with different substances. Methods: Sixty acrylic teeth $(n=10)$ were filled with pastes that associated $\mathrm{Ca}(\mathrm{OH})_{2}$ with the following substances: benzalkonium chloride $5 \%(\mathrm{G} 1)$ and 50\% (G2) both in propylene glycol, arnica glycolic extract (G3), green tea glycolic extract (G4), Calen/PMCC ${ }^{\text {TM }}$ (G5), and Calen ${ }^{\mathrm{TM}}$ (G6). In the group G1 to G4 were used $1 \mathrm{~g}$ of $\mathrm{Ca}(\mathrm{OH})_{2}$ powder with $0,8 \mathrm{~g}$ of vehicle. $\mathrm{pH}$ and $\mathrm{Ca}^{2+}$ release was measured after 7, 15, and 30 days. For solubility, micro-CT was used immediately and at the periods of 7,15 , and 30 days. For the antimicrobial analysis, a biofilm of $E$. faecalis was induced in vitro on bovine dentin discs. Live/dead viability dye and confocal scanning microscopy were used. Results: The highest $\mathrm{pH}$ values occurred on the first 7 days, and the G6, $\mathrm{G} 1, \mathrm{G} 3$, and $\mathrm{G} 5$ presented the highest $\mathrm{pH}$ values at this period $(P<0.05)$. $\mathrm{Ca}^{2+}$ release was higher in all groups at 7 days, with the highest values observed in G1, G5, and G6. The volume of all pastes showed no significant difference in the intragroup analysis at 7 and 15 days ( $P<0.05$ ). G1 and G2 showed the highest antimicrobial action $(P<0.05)$. For the biovolume, there was difference between the $\mathrm{G} 6$ and the other groups $(P>0.05)$ with $G 1$ presenting the lowest values. Conclusion: Benzalkonium chloride $5 \%$ increases the antimicrobial action of the $\mathrm{Ca}\left(\mathrm{OH}_{2}\right)$, without impairs physicochemical properties.

Keywords: Anti-infective agents. Biofilms. Calcium hydroxide. Root canal filling materials. Chemical phenomena. 


\section{Introduction}

The aim of endodontic treatment of teeth with apical periodontitis is to eliminate microorganisms from the root canal system ${ }^{1}$. However, root canal preparation, due to its anatomical complexity, is not totally effective in complete disinfection, requiring the use of intracanal dressing ${ }^{2}$. Calcium hydroxide $\left(\mathrm{Ca}(\mathrm{OH})_{2}\right)$ paste has been the most widely used intracanal medication for this purpose ${ }^{3}$. Its mechanism of action involves the dissociation in calcium $\left(\mathrm{Ca}^{2+}\right)$ and hydroxyl $(\mathrm{OH}-)$ ions, showing biological properties such as antimicrobial activity, tissue dissolution capacity and inhibition of osteoclast activity ${ }^{4-5}$. The association of $\mathrm{Ca}(\mathrm{OH})_{2}$, with inert vehicles has demonstrated limited antimicrobial effectiveness, especially against Enterococcus Faecalis ${ }^{3}$. Therefore, the association with antiseptic substances to potentiate the antimicrobial activity of the paste has been recommended 6 .

Different substances and vehicles have been proposed to be associated with $\mathrm{Ca}(\mathrm{OH})_{2}$ for improvement of its antimicrobial properties? ${ }^{7}$. Camphorated paramonochlorophenol (CPMC) is a phenolic compound used as root canal disinfectant and is one of these substances ${ }^{6}$. CPMC breaks the bacterial cytoplasmic membrane, denatures proteins, and inactivates enzymes such as oxidases and dehydrogenases, having a bactericidal effect, in addition to the release of chlorine, which is an antibacterial agent. The literature suggests that the association of $\mathrm{Ca}(\mathrm{OH})_{2} / \mathrm{CPMC}$ increases the spectrum of action and antimicrobial efficacy, in addition to greater dentinal penetration, when compared to the association of $\mathrm{Ca}(\mathrm{OH})_{2}$, with inert vehicles ${ }^{6-8}$.

Phytotherapy has been gaining popularity nowadays in the prevention and treatment of diseases because it causes few adverse effects and is inexpensive ${ }^{8}$. Green tea (Camelia sinensis) is a widely consumed beverage in many parts of the world ${ }^{8}$. It is rich in flavonoids, polyphenols, and catechins, which have potent antioxidant properties and eliminate free radicals ${ }^{8}$. Furthermore, it presents favorable results in the antimicrobial action against $E$. faecalis in biofilm and planktonic forms, which can be justified by the generation of hydroxyl radical ${ }^{9}$. Arnica is another vegetable substance with active ingredients such as sesquiterpene lactones, helenalin 11-alpha, 13-dihydroelenanine, and esters, as well as acetic, isobutyric, methacrylic, and other carboxylic acids, with anti-inflammatory properties, and also containing potent immunostimulants ${ }^{10,11}$. However, it has a low antimicrobial efficacy when used in isolation on endodontic microorganisms ${ }^{12}$. Its root extract is used externally to treat bruises, sprains, rheumatic pain, phlebitis, and skin inflammation, and as homeopathic preparations for the stimulation of the immune system ${ }^{10}$.

Another vehicle that might be associated with $\mathrm{Ca}(\mathrm{OH})_{2}$, because of its antimicrobial activity, is benzalkonium chloride (BC), which is a surfactant that presents a quaternary ammonium compound that can change cell penetrability, altering cytoplasmic components and leading to the death of bacteria, besides showing activity against viruses, fungi, and protozoa ${ }^{12-15}$. Arias-Moliz et al. ${ }^{14}$ (2015) demonstrated that the addition of this compound to endodontic cements, promoted significant improvements in antimicrobial and antibiofilm activity without affecting its properties, eliminating E. faecalis. Despite the existing literature on the characteristics and proper- 
ties of these substances, little is known about the impact of the association of other substances, such as herbal compounds and benzalkonium chloride, on the physicochemical properties and antimicrobial activity of $\mathrm{Ca}(\mathrm{OH})_{2}$, pastes. Therefore, the aim of this study was to evaluate the $\mathrm{pH}$, calcium ion release, solubility, and antimicrobial activity against Enterococcus faecalis biofilm, of pastes that associate benzalkonium chloride, arnica glycolic extract, green tea glycolic extract and CPMC with $\mathrm{Ca}(\mathrm{OH})_{2}$. The null hypothesis tested is that these substances do not influence in the antimicrobial activity and physicochemical properties of $\mathrm{Ca}(\mathrm{OH})_{2}$ paste.

\section{Materials and Methods}

\section{Experimental pastes}

Six $\mathrm{Ca}(\mathrm{OH})_{2}$ pastes were evaluated and their compositions are shown in table 1.

Table 1. Composition of the $\mathrm{Ca}(\mathrm{OH})_{2}$ pastes used.

\begin{tabular}{|c|c|}
\hline Group & Composition \\
\hline G1 & $\begin{array}{l}\mathrm{Ca}(\mathrm{OH})_{2} \text { p.a (Biodinâmica, Londrina, Brazil) + benzalkonium chloride } 5 \% \text { - (Bauru Fórmulas, } \\
\text { São Paulo, Brazil) in propylene glycol (CH/CB5) }\end{array}$ \\
\hline G2 & $\begin{array}{c}\mathrm{Ca}(\mathrm{OH})_{2} \text { p.a (Biodinâmica, Londrina, Brazil) + benzalkonium chloride } 50 \% \text { (Bauru Fórmulas, } \\
\text { São Paulo, Brazil) in propylene glycol (CH/CB50) }\end{array}$ \\
\hline G3 & $\mathrm{Ca}(\mathrm{OH})_{2}$ p.a (Biodinâmica, Londrina, Brazil) + arnica glycolic extract (CH/ARN) \\
\hline G4 & $\begin{array}{c}\mathrm{Ca}(\mathrm{OH})_{2} \text { p.a (Biodinâmica, Londrina, Brazil) }+ \text { green tea glycolic extract (Camellia sinensis } \\
\text { leaf extract) }(\mathrm{CH} / \mathrm{GT})\end{array}$ \\
\hline G5 & $\begin{array}{l}\text { Calen paste CPMC (CH/CPMC) (SS White Artigos Dentarios Ltd, Rio de Janeiro, Brazil) - } \\
\text { composed by calcium hydroxide }(2.5 \mathrm{~g}) \text {, zinc oxide }(0.5 \mathrm{~g}) \text {, hydrogenized colophony }(0.05 \\
\text { g), polyethyleneglycol } 400(1.75 \mathrm{~mL}) \text {, and camphorated paramonochlorophenol }(0.15 \mathrm{~mL}) \text {. }\end{array}$ \\
\hline G6 & $\begin{array}{c}\text { Calen paste }(\mathrm{CH})(\mathrm{SS} \text { White Artigos Dentarios Ltd, Rio de Janeiro, Brazil) - } \\
\text { calcium hydroxide }(2.5 \mathrm{~g}) \text {, zinc oxide }(0.5 \mathrm{~g}) \text {, hydrogenized colophony }(0.05 \mathrm{~g}) \text { and } \\
\text { polyethyleneglycol } 400(12.75 \mathrm{ml})\end{array}$ \\
\hline
\end{tabular}

In the group G1 to G4 were used $1 \mathrm{~g}$ of calcium hydroxide powder with $0,8 \mathrm{~g}$ of vehicle and the final consistency of the pastes was similar to that of toothpaste. In the groups $\mathrm{G} 5$ and $\mathrm{G} 6$ were used 1,8g of the paste to fill the canal.

\section{Analyses of $\mathrm{pH}$, calcium ion release, and solubility}

For the $\mathrm{pH}$ and calcium ion release analyses, 60 artificial acrylic resin maxillary central incisors $(N=10)$ with an artificial foramen standardized to a diameter of $400 \mu \mathrm{m}$ were filled, using a lentulo drills \#30 (Dentsply/ Maillefer, Ballaigues, Switzerland). After that, the roots were analyzed using a micro-CT camera to guarantee the complete filling. Then, the crowns were sealed with a composite resin and the teeth were individually immersed in tubes containing $10 \mathrm{~mL}$ of deionized water $(\mathrm{pH}$ 7.15). The tubes were hermetically sealed and taken to the oven at $37^{\circ} \mathrm{C}$. After 7,15 , and 30 days, the specimens were transferred to a new tube with the same volume of deionized water. The $\mathrm{pH}$ and calcium ion released were measured in each time interval immediately after the removal of the teeth from the tubes. 
A pH meter (model 371; Micronal, São Paulo, SP, Brazil) was used for the determination of the $\mathrm{pH}$. To assure the accuracy of the device, constant measurements were performed with known buffers at $\mathrm{pH}$ of 4,7 , and 14 . After the specimen removal, the tube was taken to a shaker and agitated for 5 seconds. After agitation, the liquid was poured into a beaker and then put in contact with the device's electrode.

Calcium ion release was measured using an atomic absorption spectrophotometer (AA6800; Schimadzu, Tokyo, Japan) equipped with a calcium-specific hollow cathode lamp. Calcium release and pH were performed in triplicate.

The solubility analyses were performed with the same teeth used for the determination of the $\mathrm{pH}$ and calcium ion release. For this experiment, immediately after the acrylic teeth were filled with the experimental pastes and sealed with the composite resin they were scanned with a microcomputed tomography (SkyScan 1174v2; Skyscan, Kontich, Belgium) to obtain the baseline values. The imaging parameters used were: voxel size of $19.70 \mu \mathrm{m}$ and $360^{\circ}$ at a rotation step of $0.5^{\circ}$. Then, the teeth were immersed in plastic bottles and stored as previously described. At the time intervals of 7,15 , and 30 days, the teeth were removed from the bottles and scanned again before they were inserted in the new tubes. The images obtained were reconstructed and the volume $\left(\mathrm{mm}^{3}\right)$ was measured with the aid of a software (CTan v1.11.10.0, Sky-Scan). Solubility values at baseline and after the tests were recorded. The percentage of solubility in each period was also determined.

\section{Analyses of antimicrobial activity}

To test the antimicrobial activity of the pastes, dentin discs were removed from bovine teeth with fully developed roots. For this, trephine burs ( $4 \times 4 \mathrm{~mm})$ were used coupled to a handpiece device and placed perpendicular to bovine roots. The trephine was forced from the mesial to the distal portion of cervical and middle thirds, under abundant irrigation, so that were obtained four dentin discs per tooth. Then, the discs were polished with silicon carbide abrasive papers (Buehler Ltd, Lake Bluff, Illinois) of 600,400 , and 200 granulations, providing a mean thickness of 0.8-1.0 mm of dentin disks. Afterwards, the specimens were submitted to an ultrasonic bath of 5 min each, with $1 \%$ sodium hypochlorite and $17 \%$ EDTA to remove smear layer, and were subsequently sterilized in an autoclave.

After confirmation of the strain purity by Gram staining and colony morphology, $15 \mathrm{~mL}$ Enterococcus faecalis standard strain (American Type Culture Collection [ATCC] 29212) were put into $3 \mathrm{~mL}$ sterile brain-heart infusion (BHI; Oxoid, Basingstoke, UK) at $37^{\circ} \mathrm{C}$ in air for growth overnight. Following, bacterial density was adjusted at $10^{8}$ cells/mL with a spectrophotometer (UV-VISIBLI, Shimadzu, Japan) at an optical density of 1 at $600 \mathrm{~nm}$ according to the $0.5 \mathrm{MacF}$ arland standard. The dentin surfaces were then infected for biofilm grown: 1 dentin block $+100 \mu \mathrm{L}$. faecalis $+900 \mu \mathrm{L} \mathrm{BHI}$ were inserted into each well of a 24-well multiwell plate. The latter was kept under agitation in an oven at $37^{\circ} \mathrm{C}$ (Q816M20; Composed of Scientific Chemis LTDA, Diadema, SP, Brazil) for 21 days. To avoid nutrient deficiency, the culture medium was completely replaced every 48 hours, without addition of new microorganisms. For the antimicrobial test, dentin samples were immersed in experimental pastes and incubated at $37^{\circ} \mathrm{C}$ for 7 days. In the control group, the biofilm received no treatment. 
After this period, the pastes were washed out inserting the disc in a recipient with distilled water until the complete removal of the paste under the disc, after that samples were stained with $15 \mu \mathrm{m}$ of Syto 8/propidium iodide (Live/Dead Technique-In Vitro Gen) for 15 minutes. After staining, the samples were taken to a confocal laser scanning microscope (Leica, Mannheim, Germany) to obtain images from the surface with a 40x magnification. The biovolume and percentage of live cells were calculated with the aid of the biolmage_L software (www.bioimagel.com).

The data obtained in the $\mathrm{pH}$ analysis, calcium ion release, solubility, and antimicrobial activity were analyzed for normality by the Shapiro-Wilk test. As the values $\mathrm{pH}$, calcium ion release, and solubility presented a normal distribution the analysis of variance ANOVA with a post-hoc Tukey's test was applied for statistical comparison of the data. Because of the absence of a normal distribution, the Kruskal-Wallis and Dunn's post-hoc tests were used to compare the antimicrobial activity. The level of significance was set at $5 \%$.

\section{Results}

Table 2 shows the median (Med), minimum and maximum (Min - Max) values for the calcium and hydroxyl ions release $(\mathrm{mg} / \mathrm{L})$ by the pastes in the periods analyzed. In this period the higher alkalinity values were achieved by the viscous pastes $\mathrm{CH} / \mathrm{CB} 5$ (G1), CH/CPMC (G5) and CH (G6) with exception of CH/CB50 (G2). ( $\mathrm{P}<0.05)$. The $\mathrm{CH} / \mathrm{GT}(\mathrm{G} 4)$ presented the lowest values for calcium ion release in all periods. $(\mathrm{P}<0.05)$. For the groups CH/CB5 (G1), CH/CB50 (G2), CH/CPMC (G5), and CH (G6) the intragroup analysis revealed a statistically significant reduction in calcium ion

Table 2. Median (Med), minimum and maximum (Min - Max) values for the calcium and hydroxyl ions release $(\mathrm{mg} / \mathrm{L})$ from the pastes in the different periods of time.

\begin{tabular}{|c|c|c|c|c|c|c|}
\hline \multirow[b]{2}{*}{ GROUPS } & \multicolumn{2}{|c|}{7 days } & \multicolumn{2}{|c|}{15 days } & \multicolumn{2}{|c|}{30 days } \\
\hline & $\begin{array}{c}\mathrm{pH} \\
\text { Med } \\
(\text { Min - Max })\end{array}$ & $\begin{array}{c}\mathrm{Ca}^{2+} \\
\mathrm{Med} \\
(\mathrm{Min}-\mathrm{Max})\end{array}$ & $\begin{array}{c}\mathrm{pH} \\
\text { Med } \\
(\operatorname{Min}-\mathrm{Max})\end{array}$ & $\begin{array}{c}\mathrm{Ca}^{2+} \\
\mathrm{Med} \\
(\mathrm{Min}-\mathrm{Max})\end{array}$ & $\begin{array}{c}\mathrm{pH} \\
\text { Med } \\
(\text { Min - Max })\end{array}$ & $\begin{array}{c}\mathrm{Ca}^{2+} \\
\text { Med } \\
(\mathrm{Min}-\mathrm{Max})\end{array}$ \\
\hline $\begin{array}{l}\mathrm{G} 1 \\
(\mathrm{CH} / \mathrm{CB} 5)\end{array}$ & $\begin{array}{c}11.45 \\
(10.93-11.78)^{\mathrm{AB}}\end{array}$ & $\begin{array}{c}129.3 \\
(82.12-355.7)^{\mathrm{AB.a}}\end{array}$ & $\begin{array}{c}8.48 \\
(7.9-9.6)^{\mathrm{D}}\end{array}$ & $\begin{array}{c}55.07 \\
(50.92-57.86)^{\text {A.b }}\end{array}$ & $\begin{array}{c}7.9 \\
(7.74-8.06)^{C D}\end{array}$ & $\begin{array}{c}29.36 \\
(15.26-57.84)^{A B . b}\end{array}$ \\
\hline $\begin{array}{l}\mathrm{G} 2 \\
(\mathrm{CH} / \mathrm{CB} 50)\end{array}$ & $\begin{array}{c}10.67 \\
(10.39-11.29)^{C D}\end{array}$ & $\begin{array}{c}64.03 \\
(38.76-77.99)^{\text {BC.a }}\end{array}$ & $\begin{array}{c}9.37 \\
(8.4-10.64)^{\mathrm{ABC}}\end{array}$ & $\begin{array}{c}18.72 \\
(13.06-49.65)^{A B . b}\end{array}$ & $\begin{array}{c}8.06 \\
(7.88-8.33)^{\mathrm{BCD}}\end{array}$ & $\begin{array}{c}18.33 \\
(0-49.05)^{A B . b}\end{array}$ \\
\hline $\begin{array}{l}\mathrm{G} 3 \\
(\mathrm{CH} / \mathrm{ARN})\end{array}$ & $\begin{array}{c}10.93 \\
(10.36-11.26)^{\mathrm{BC}}\end{array}$ & $\begin{array}{c}18.77 \\
(8.71-33.48)^{c . a}\end{array}$ & $\begin{array}{c}10.54 \\
(9.33-10.85)^{\mathrm{A}}\end{array}$ & $\begin{array}{c}9.93 \\
(3.59-30.84)^{\text {BC.a }}\end{array}$ & $\begin{array}{c}8.52 \\
(8.32-8.65)^{A}\end{array}$ & $\begin{array}{c}21.53 \\
(9.82-29.43)^{\text {в.а }}\end{array}$ \\
\hline $\begin{array}{l}\mathrm{G} 4 \\
(\mathrm{CH} / \mathrm{GT})\end{array}$ & $\begin{array}{c}10.27 \\
(9.5-10.82)^{\mathrm{D}}\end{array}$ & $\begin{array}{c}2.92 \\
(0.11-168)^{\mathrm{c.a}}\end{array}$ & $\begin{array}{c}8.73 \\
(8.3-9.33)^{\mathrm{CD}}\end{array}$ & $\begin{array}{c}1.2 \\
(0.15-9.87)^{\text {c.ab }}\end{array}$ & $\begin{array}{c}8.14 \\
(8-8.4)^{\mathrm{BC}}\end{array}$ & $\begin{array}{c}0.475 \\
(0.13-4.76)^{c . b}\end{array}$ \\
\hline $\begin{array}{l}\text { G5 } \\
\text { (CH/CPMC) }\end{array}$ & $\begin{array}{c}11.63 \\
(11.32-11.94)^{A}\end{array}$ & $\begin{array}{c}219.6 \\
(150.5-446.6)^{\text {AB.a }}\end{array}$ & $\begin{array}{c}9.57 \\
(9-10.78)^{A B}\end{array}$ & $\begin{array}{c}22.77 \\
(3.28-24.16)^{\text {BC.b }}\end{array}$ & $\begin{array}{c}7.88 \\
(7.82-7.96)^{\mathrm{D}}\end{array}$ & $\begin{array}{c}14.02 \\
(6.8-20.7)^{\text {BC.b }}\end{array}$ \\
\hline $\begin{array}{l}\mathrm{G} 6 \\
(\mathrm{CH})\end{array}$ & $\begin{array}{c}11.64 \\
(9.2-12.25)^{A B}\end{array}$ & $\begin{array}{c}340.3 \\
(69.93-899.3)^{\text {A.a }}\end{array}$ & $\begin{array}{c}8.98 \\
(8.43-10.46)^{\mathrm{BCD}}\end{array}$ & $\begin{array}{c}24.93 \\
(10-33.74)^{\text {AB.b }}\end{array}$ & $\begin{array}{c}8.32 \\
(7.8-9.35)^{A B}\end{array}$ & $\begin{array}{c}45.42 \\
(36.88-51.36)^{A . b}\end{array}$ \\
\hline
\end{tabular}

*Repeated measures ANOVA with Tukey's multiple comparison test, P-value < 0.05; Different lowercase letters in rows indicate statistically significant intragroup differences; ANOVA with Tukey's multiple comparison test, $P$-value $<0.05$; Different uppercase letters in columns indicate statistically significant intergroup differences in the same time period. $\mathrm{CH} / \mathrm{CB} 5$ - Calcium hydroxide + benzalkonium chloride $5 \%$; $\mathrm{CH} / \mathrm{CB} 50$ - Calcium hydroxide + benzalkonium chloride $50 \%$; $\mathrm{CH} / \mathrm{ARN}$ - Calcium hydroxide + arnica glycolic extract; $\mathrm{CH} / \mathrm{GT}$ - Calcium hydroxide + green tea glycolic extract; $\mathrm{CH} / \mathrm{CPMC}$ - Calen paste + camphorated paramonochlorophenol; $\mathrm{CH}$ - Calen paste 
release between 7 and 15 days $(P<0.05)$, however, between 15 and 30 days, no difference was observed $(P>0.05)$.

The median (Med), minimum and maximum (Min - Max) for the volume $\left(\mathrm{mm}^{3}\right)$ of the different experimental pastes over time is presented in the Table 3. In the intragroup analysis, in all groups, no statistical significant difference was seen between initial volume and the volume after 7 days. $\mathrm{CH} / \mathrm{CB} 5$ (G1) presented the lowest solubility, showing statistical reduction of the initial volume just in 30 days. $\mathrm{CH} / \mathrm{CB} 50$ (G2), $\mathrm{CH} / \mathrm{ARN}(\mathrm{G} 3)$ and $\mathrm{CH} / \mathrm{GT}$ (G4) revealed similar solubility over time, with significant volume reduction after 15 days. $\mathrm{CH} / \mathrm{CPMC}(\mathrm{G} 5)$ and $\mathrm{CH}(\mathrm{G} 6)$ presented no statistical significant difference in the volume between 15 and 30 days.

Table 4 shows the median (Med), minimum and maximum (Min - Max) values for the biovolume and the percentage of living bacteria in the biofilm after contact with

Table 3. Median (Med), minimum and maximum (Min - Max) values of the experimental pastes volumes $\left(\mathrm{mm}^{3}\right)$ in the different periods of time

\begin{tabular}{lcccc}
\hline \multirow{2}{*}{ GRouPS } & Initial volume & $\mathbf{7}$ days & 15 days & 30 days \\
\cline { 2 - 5 } & Med (Min - Max) & Med (Min - Max) & Med (Min - Max) & Med (Min - Max) \\
\hline G1 (CH/CB5) & $1.63(1.22-2.24)^{\mathrm{a}}$ & $1.6(0.99-2.23)^{\mathrm{a}}$ & $1.42(0.79-2.06)^{\mathrm{ab}}$ & $1.36(0.57-1.94)^{\mathrm{b}}$ \\
\hline $\mathrm{G} 2(\mathrm{CH} / \mathrm{CB} 50)$ & $2.26(3.44-2.01)^{\mathrm{a}}$ & $2.13(2.64-1.72)^{\mathrm{ab}}$ & $1.99(2.46-1.35)^{\mathrm{b}}$ & $1.99(2.47-1.45)^{\mathrm{b}}$ \\
\hline $\mathrm{G} 3(\mathrm{CH} / \mathrm{ARN})$ & $1.92(2.30-1.41)^{\mathrm{a}}$ & $1.840(2.18-1.17)^{\mathrm{ab}}$ & $1.67(2.18-1.04)^{\mathrm{b}}$ & $1.67(2.18-0.98)^{\mathrm{b}}$ \\
\hline $\mathrm{G} 4(\mathrm{CH} / \mathrm{GT})$ & $3.35(4.02-1.24)^{\mathrm{a}}$ & $2.53(3.00-1.24)^{\mathrm{ab}}$ & $2.37(2.53-1.24)^{\mathrm{b}}$ & $2.37(2.53-1.24)^{\mathrm{b}}$ \\
\hline $\mathrm{G} 5(\mathrm{CH} / \mathrm{CPMC})$ & $2.37(2.18-2.73)^{\mathrm{a}}$ & $2.21(2.09-2.38)^{\mathrm{ab}}$ & $0.40(0.19-0.67)^{\mathrm{bc}}$ & $0.37(0.07-0.62)^{\mathrm{c}}$ \\
\hline $\mathrm{G6}(\mathrm{C})$ & $1.64(1.15-2.59)^{\mathrm{a}}$ & $1.58(1.08-2.50)^{\mathrm{ab}}$ & $1.45(0.93-2.18)^{\mathrm{bc}}$ & $1.39(0.71-1.95)^{\mathrm{c}}$ \\
\hline
\end{tabular}

*repeated measures with Friedman and Dunn's multiple comparison test, P-value < 0.05; Different lowercase letters in rows indicate statistically significant intragroup differences; $\mathrm{CH} / \mathrm{CB} 5$ - Calcium hydroxide +

benzalkonium chloride 5\%; $\mathrm{CH} / \mathrm{CB} 50$ - Calcium hydroxide + benzalkonium chloride 50\%;CH/ARN - Calcium hydroxide + arnica glycolic extract; $\mathrm{CH} / \mathrm{GT}$ - Calcium hydroxide + green tea glycolic extract; $\mathrm{CH} / \mathrm{CPMC}$ - Calen paste + camphorated paramonochlorophenol; $\mathrm{CH}$ - Calen paste

Table 4. Median (Med), minimum and maximum (Min - Max) values of the percentage of live cells and biovolume of the biofilm after the contact with the experimental pastes for 7 days.

\begin{tabular}{lcc}
\hline \multirow{2}{*}{ GRouPS } & \% of live cells & Biovolume \\
\cline { 2 - 3 } & Med (Min - Max $)$ & Med (Min - Max) \\
\hline G1 (CH/CB5) & $13.39(5.75-21.57)^{\mathrm{B}}$ & $56.673(5.182-451.825)^{\mathrm{B}}$ \\
\hline $\mathrm{G} 2(\mathrm{CH} / \mathrm{CB} 50)$ & $6.4(2.59-16.64)^{\mathrm{B}}$ & $67.114(22.511-577.933)^{\mathrm{AB}}$ \\
\hline $\mathrm{G} 3(\mathrm{CH} / \mathrm{ARN})$ & $70.48(54.15-76.16)^{\mathrm{A}}$ & $65.277(12.295-460.183)^{\mathrm{B}}$ \\
\hline $\mathrm{G} 4(\mathrm{CH} / \mathrm{GT})$ & $81.43(72.38-92.63)^{\mathrm{A}}$ & $167.706(16.582-1270.006)^{\mathrm{AB}}$ \\
\hline $\mathrm{G} 5(\mathrm{CH} / \mathrm{CPMC})$ & $58.73(47.34-77.1)^{\mathrm{A}}$ & $146.641(6.947-550.611)^{\mathrm{AB}}$ \\
\hline G6 (C) & $54.81(34.13-87.86)^{\mathrm{A}}$ & $133.222(5.605-800.540)^{\mathrm{AB}}$ \\
\hline Control & $79.14(68.30-86.56)^{\mathrm{A}}$ & $255.94(12.882-1222.006)^{\mathrm{A}}$ \\
\hline
\end{tabular}

*Kruskal-Wallis with Dunn's post-hoc, P-value $<0.05$; Different uppercase letters in columns indicate statistically significant intergroup differences. $\mathrm{CH} / \mathrm{CB} 5$ - Calcium hydroxide + benzalkonium chloride $5 \%$; $\mathrm{CH} / \mathrm{CB} 50$ -

Calcium hydroxide + benzalkonium chloride $50 \% ; \mathrm{CH} / \mathrm{ARN}$ - Calcium hydroxide + arnica glycolic extract; $\mathrm{CH} / \mathrm{GT}$ -

Calcium hydroxide + green tea glycolic extract; $\mathrm{CH} / \mathrm{CPMC}$ - Calen paste + camphorated paramonochlorophenol; $\mathrm{CH}$ - Calen paste 
the experimental pastes for 7 days (Figure 1). The pastes with $5 \%$ benzalkonium chloride $\mathrm{CH} / \mathrm{CB} 5$ (G1) and $\mathrm{CH} / \mathrm{CB} 50$ (G2) were similar $(\mathrm{P}>0.05)$ and showed the lowest percentage of living bacteria, with statistically significant differences in comparison with all other groups $(P<0.05)$. A reduction on the biovolume of the biofilm was seen in all groups when compared to the control, with the best results for $\mathrm{CH} / \mathrm{CB} 5$ and $\mathrm{CH} / \mathrm{ARN}(\mathrm{P}<0.05)$.

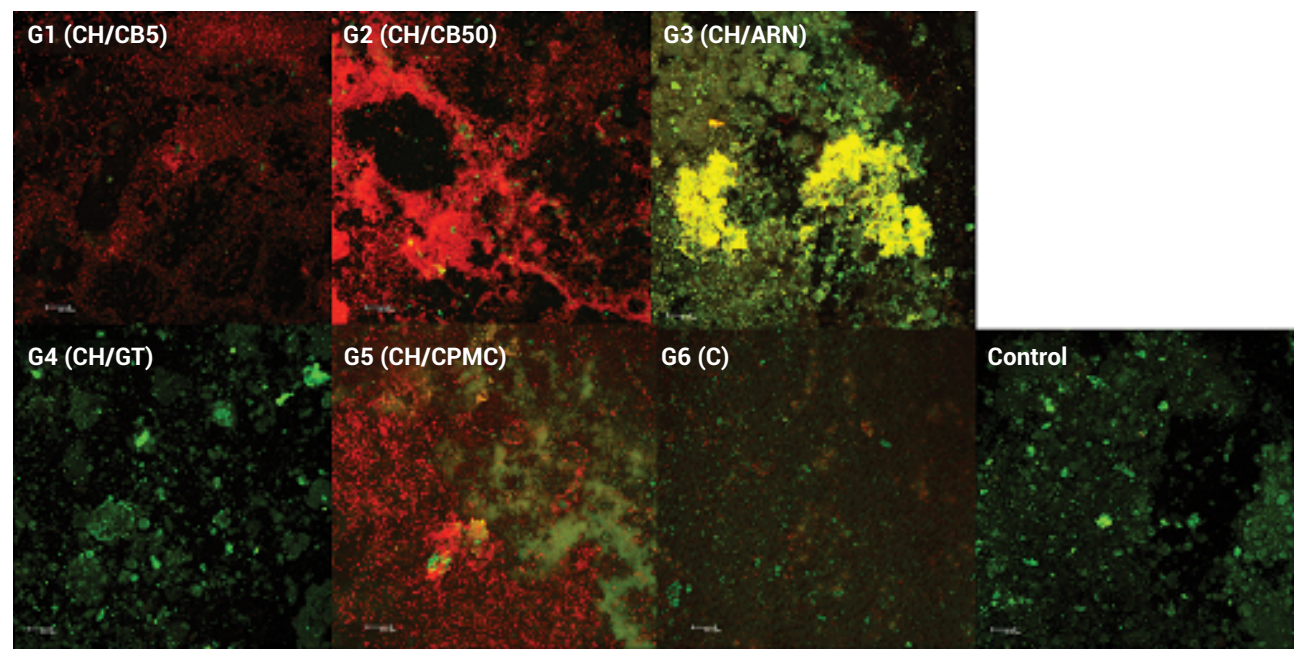

Figure 1. Confocal laser scanning microscopy of biofilms treated with benzalkonium chloride 5\% (G1) and $50 \%$ (G2), arnica glycolic extract (G3), green tea glycolic extract (G4), camphorated paramonochlorophenol (CMCP) (G5), and Calen (G6) (control). Live cells are indicated in green, and dead cells are indicated in red. Each picture represents an area of $275 \times 275 \mathrm{~mm}$.

\section{Discussion}

In the present study, different substances with phytotherapeutic and antiseptic properties were associated with the $\mathrm{Ca}(\mathrm{OH})_{2}$ paste to evaluate their effects against E. faecalis biofilms. The results obtained with regard to $\mathrm{pH}$, after 7 days, reinforce that the association with viscous vehicles, such as propylene glycol, is related to a greater diffusion of hydroxyl and calcium ions through dentinal tubules, and the penetration into the bacterial cell membrane ${ }^{16-18}$. Except for $\mathrm{G} 2$, where the high concentration of the additive may have interfered with the action of $\mathrm{Ca}(\mathrm{OH})_{2}$. Similar results were observed in the released $\mathrm{Ca}^{2}+$.

Hydroxyl ions are able to diffuse rapidly in the first 24 hours and reach a plate after 2 weeks in the apical region ${ }^{3}$. In our results, the $\mathrm{pH}$ peak was in the first week, and its decrease over the time could be explained by the absence of dentinal permeability, once in artificial teeth the ions were able to leave the canal space only through the foramen. However, even decreasing the ions release all the pastes maintained an alkaline $\mathrm{pH}$ in the external environment, which is important for the biological and antimicrobial activities of the medication ${ }^{2,3,16,18}$. Estrela et al. ${ }^{2}$ showed that the $\mathrm{pH}$ necessary for activation of alkaline phosphatase ranges from 8.6 to 10.3. 
Regarding solubility, most studies use analytical methods based on ANSI / ADA No. 57 or ISO $6876^{19,20}$. However, this type of methodology was not applicable to pastes due to the absence of setting. Thus, in this study, the solubility was measured by inserting the pastes in simulated canals. After, they were digitized in micro-CT to determine the volume of the paste in different periods of time, enabling the comparison of the volume lost over time ${ }^{3,21}$. High solubility is undesirable, as it interferes with the paste's direct contact with microorganisms ${ }^{22,23}$. On the other hand, solubility is related to the ion release and consequently the alkalization of the environment ${ }^{16}$, in this sense there must be a balance. There was a decrease in the volume of pastes over time (15 and 30 days), indicating solubility that resulted from their immersion in the liquid, as it occurs in clinical scene, where fluids gain the root canal through the foramen and promote the solubility of the medication ${ }^{17,18}$.

E. faecalis, mainly in the form of biofilm, can survive in alkaline $\mathrm{pH}$ and be resistant to $\mathrm{Ca}(\mathrm{OH}) 2$ paste with an inert vehicle ${ }^{24}$, reaffirming the results of the present study. Studies have shown that calcium hydroxide may need 10 days to disinfect dentinal tubules with facultative bacteria ${ }^{25,26}$, suggesting that $E$. faecalis exhibits the ability to maintain the $\mathrm{pH}$ homeostasis of the medium ${ }^{17}$. Therefore, the association of $\mathrm{Ca}(\mathrm{OH})_{2}$ with antiseptic vehicles is recommended to enhance its antimicrobial effect.

Although CPMC mixed with calcium hydroxide appear to increase the antimicrobial action 4,17,27 in our results it was not evident. Lima et al. ${ }^{19}$ (2012) showed that CPMC / Calen maintained for 7 days did not show an effective antimicrobial action, but after 14 days, it resulted in $100 \%$ elimination of the bacteria. The authors suggested that the relation between the phenol and the PEG could decrease the release of the group phenolic ${ }^{28}$, resulting in a less active paste against biofilm in the initial periods.

Studies show the inhibitory effect of green tea on the growth of S. mutans ${ }^{29-31}$, suggesting that its local application can reduce the acidity of saliva and bacterial plaque, acting as a preventive measure against caries ${ }^{29}$. However, the association with $\mathrm{Ca}(\mathrm{OH})_{2}$ did not improve the antimicrobial activity against $E$. faecalis, compared to the positive control. A similar result was observed in the arnica group (G3), another phytotherapeutic substance rich in flavonoids and derived from thymol ${ }^{10}$.

The addition of benzalkonium chloride to $\mathrm{Ca}(\mathrm{OH})_{2}$ potentiated the release of calcium and hydroxyl ions, favoring their antimicrobial activity, reaffirming the results obtained by Jaramillo et al. ${ }^{32}$ (2012), where approximately $70 \%$ of the bacterial biofilm was reduced with the use of benzalkonium chloride, suggesting that this surfactant interferes with the cellular mechanism of bacterial adhesion. The association of this substance with irrigating solutions or sealers presented good antimicrobial activity ${ }^{12-14,32}$.

Thus, the association of $\mathrm{Ca}(\mathrm{OH})_{2}$ with the suggested compounds does not seem to significantly alter its $\mathrm{pH}$, volume, and solubility, based on this, benzalkonium chloride in high concentration is not recommended, in spite of $\mathrm{BC}$ is recognized by the United States Pharmacopoeia and it is used in numerous toothpastes and mouthrinses ${ }^{33}$. Clinically, a lower concentration may be used in association with $\mathrm{Ca}(\mathrm{OH})_{2}$, promoting greater decontamination in a safe manner by reducing any possibility of side effects if extruded into the periapical tissue. 
In conclusion, the results of this study showed that the type of vehicle and substances associated with $\mathrm{Ca}(\mathrm{OH})_{2}$ powder can affect the antimicrobial effects, solubility, and ion release of the pastes obtained. After a comparison of all physicochemical and antimicrobial properties of $\mathrm{Ca}(\mathrm{OH})_{2}$ pastes tested, it was possible to conclude that association with $5 \%$ benzalkonium chloride seems to offer the greatest advantages since it presented a high ion release, low solubility, and significant antimicrobial activity.

\section{Acknowledgements}

The work was supported by State of Sao Paulo Research Foundation, FAPESP (2018/26299-6). The authors deny any conflicts of interest related to this study.

\section{References}

1. Gründling GL, Melo TA, Montagner F, Scarparo RK, Vier-Pelisser FV. QMix $®$ irrigant reduces lipopolysacharide (LPS) levels in an in vitro model. J Appl Oral Sci. 2015 Jul-Aug;23(4):431-5 doi: 10.1590/1678-775720140488.

2. Estrela C, Pécora JD, Souza-Neto MD, Estrela CR, Bammann LL. Effect of vehicle on antimicrobial properties of calcium hydroxide pastes. Braz Dent J. 1999;10(2):63-72.

3. Zancan RF, Vivan RR, Milanda Lopes MR, Weckwerth PH, de Andrade FB, Ponce JB, et al. Antimicrobial Activity and Physicochemical Properties of Calcium Hydroxide Pastes Used as Intracanal Medication. J Endod. 2016 Dec;42(12):1822-8. doi: 10.1016/j.joen.2016.08.017.

4. Siqueira JF Jr, Lopes HP. Mechanisms of antimicrobial activity of calcium hydroxide: a critical review. Int Endod J. 1999 Sep;32(5):361-9. doi: 10.1046/j.1365-2591.1999.00275.x.

5. Siqueira JF Jr, de Uzeda M. Influence of different vehicles on the antibacterial effects of calcium hydroxide. J Endod. 1998 Oct;24(10):663-5. doi: 10.1016/S0099-2399(98)80151-9.

6. Gomes BP, Ferraz CC, Vianna ME, Rosalen PL, Zaia AA, Teixeira FB, et al. In vitro antimicrobial activity of calcium hydroxide pastes and their vehicles against selected microorganisms. Braz Dent J. 2002;13(3):155-61. doi: 10.1590/s0103-64402002000300002.

7. Lima RA, Carvalho CB, Ribeiro TR, Fonteles CS. Antimicrobial efficacy of chlorhexidine and calcium hydroxide/camphorated paramonochlorophenol on infected primary molars: a split-mouth randomized clinical trial. Quintessence Int. 2013 Feb;44(2):113-22. doi: 10.3290/j.qi.a28932.

8. George DE, Shetty R, Shetty PJ, Gomes LA. An In vitro Study to Compare the Effect of Different Types of Tea with Chlorhexidine on Streptococcusmutans. J Clin Diagn Res. 2017 Sep;11(9):ZC05-7. doi: 10.7860/JCDR/2017/26581.10538

9. Lee P, Tan KS. Effects of Epigallocatechin gallate against Enterococcus faecalis biofilm and virulence. Arch Oral Biol. 2015 Mar;60(3):393-9. doi: 10.1016/j.archoralbio.2014.11.014.

10. Adkison JD, Bauer DW, Chang T. The effect of topical arnica on muscle pain. Ann Pharmacother. 2010 Oct;44(10):1579-84. doi: 10.1345/aph.1P071.

11. Šutovská M, Capek P, Kočmalová M, Pawlaczyk I, Zaczyńska E, Czarny A, et al. Characterization and pharmacodynamic properties of Arnica montana complex. Int J Biol Macromol. 2014 Aug;69:214-21. doi: 10.1016/j.jibiomac.2014.05.051

12. Koo H, Gomes BP, Rosalen PL, Ambrosano GM, Park YK, Cury JA. In vitro antimicrobial activity of propolis and Arnica montana against oral pathogens. Arch Oral Biol. 2000 Feb;45(2):141-8. doi: 10.1016/s0003-9969(99)00117-x. 
13. Oguz Ahmet S, Mutluay MM, Seyfioglu Polat Z, Seseogullari Dirihan R, Bek B, Tezvergil-Mutluay A. Addition of benzalkonium chloride to self-adhesive resin-cements: some clinically relevant properties. Acta Odontol Scand. 2014 Nov;72(8):831-8. doi: 10.3109/00016357.2014.913307.

14. Arias-Moliz MT, Ruiz-Linares M, Cassar G, Ferrer-Luque CM, Baca P, Ordinola-Zapata R, et al. The effect of benzalkonium chloride additions to AH Plus sealer. Antimicrobial, physical and chemical properties. J Dent. 2015 Jul;43(7):846-54. doi: 10.1016/j.jdent.2015.05.003.

15. Gjorgievska ES, Nicholson JW, Coleman NJ, Booth S, Dimkov A, Hurt A. Component Release and Mechanical Properties of Endodontic Sealers following Incorporation of Antimicrobial Agents. Biomed Res Int. 2017;2017:2129807. doi: 10.1155/2017/2129807.

16. Camões IC, Salles MR, Chevitarese O, Gomes GC. Influence on pH of vehicle containing glycerin used with calcium hydroxide. Dent Traumatol. 2003 Jun;19(3):132-8. doi: 10.1034/j.1600-9657.2003.00114.x.

17. Chávez De Paz LE, Dahlén G, Molander A, Möller A, Bergenholtz G. Bacteria recovered from teeth with apical periodontitis after antimicrobial endodontic treatment. Int Endod J. 2003 Jul;36(7):500-8. doi: 10.1046/j.1365-2591.2003.00686.x.

18. Duarte MA, Midena RZ, Zeferino MA, Vivan RR, Weckwerth PH, Dos Santos F, et al. Evaluation of pH and calcium ion release of calcium hydroxide pastes containing different substances. J Endod. 2009 Sep;35(9):1274-7. doi: 10.1016/j.joen.2009.05.009.

19. Lima RK, Guerreiro-Tanomaru JM, Faria-Júnior NB, Tanomaru-Filho M. Effectiveness of calcium hydroxide-based intracanal medicaments against Enterococcus faecalis. Int Endod J. 2012 Apr;45(4):311-6. doi: 10.1111/j.1365-2591.2011.01976.x.

20. Pereira TC, da Silva Munhoz Vasconcelos LR, Graeff MSZ, Ribeiro MCM, Duarte MAH, de Andrade FB Intratubular decontamination ability and physicochemical properties of calcium hydroxide pastes. Clin Oral Investig. 2019 Mar;23(3):1253-62. doi: 10.1007/s00784-018-2549-0.

21. Gasperi TL, Silveira JACD, Schmidt TF, Teixeira CDS, Garcia LDFR, Bortoluzzi EA. Physical-mechanical properties of a resin-modified calcium silicate material for pulp capping. Braz Dent J. 2020 Jun;31(3):252-6. doi: 10.1590/0103-6440202003079.

22. Hungaro Duarte MA, Minotti PG, Rodrigues CT, Zapata RO, Bramante CM, Tanomaru Filho M, et al. Effect of different radiopacifying agents on the physicochemical properties of white Portland cement and white mineral trioxide aggregate. J Endod. 2012 Mar;38(3):394-7. doi: 10.1016/j.joen.2011.11.005.

23. Cavenago BC, Pereira TC, Duarte MA, Ordinola-Zapata R, Marciano MA, Bramante CM, et al. Influence of powder-to-water ratio on radiopacity, setting time, $\mathrm{pH}$, calcium ion release and a micro-CT volumetric solubility of white mineral trioxide aggregate. Int Endod J. 2014 Feb;47(2):120-6. doi: 10.1111/iej.12120.

24. Rehman K, Saunders WP, Foye RH, Sharkey SW. Calcium ion diffusion from calcium hydroxide-containing materials in endodontically-treated teeth: an in vitro study. Int Endod J. 1996 Jul;29(4):271-9. doi: 10.1111/j.1365-2591.1996.tb01381.x.

25. de Andrade Ferreira FB, Silva E Souza Pde A, do Vale MS, de Moraes IG, Granjeiro JM. Evaluation of $\mathrm{pH}$ levels and calcium ion release in various calcium hydroxide endodontic dressings. Oral Surg Oral Med Oral Pathol Oral Radiol Endod. 2004 Mar;97(3):388-92. doi: 10.1016/j.tripleo.2003.08.020.

26. Verma R, Sharma DS, Pathak AK. Antibacterial efficacy of pastes against e faecalis in primary root dentin: a confocal microscope study. J Clin Pediatr Dent. 2015 Spring;39(3):247-54. doi: 10.17796/1053-4628-39.3.247.

27. Stuart CH, Schwartz SA, Beeson TJ, Owatz CB. Enterococcus faecalis: its role in root canal treatment failure and current concepts in retreatment. J Endod. 2006 Feb;32(2):93-8. doi: 10.1016/j.joen.2005.10.049. 
28. Orstavik D, Haapasalo M. Disinfection by endodontic irrigants and dressings of experimentally infected dentinal tubules. Endod Dent Traumatol. 1990 Aug;6(4):142-9. doi: 10.1111/j.1600-9657.1990.tb00409.x.

29. Zancan RF, Calefi PHS, Borges MMB, Lopes MRM, de Andrade FB, Vivan RR, et al. Antimicrobial activity of intracanal medications against both Enterococcus faecalis and Candida albicans biofilm. Microsc Res Tech. 2019 May;82(5):494-500. doi: 10.1002/jemt.23192.

30. Awadalla HI, Ragab MH, Bassuoni MW, Fayed MT, Abbas MO. A pilot study of the role of green tea use on oral health. Int J Dent Hyg. 2011 May;9(2):110-6. doi: 10.1111/j.1601-5037.2009.00440.x.

31. Gok B, Kirzioglu Z, Kivanc M. Green tea extract solutions can control bacterial biofilms formed on space maintainers. Niger J Clin Pract. 2020 Jun;23(6):783-91. doi: 10.4103/njcp.njcp_246_19.

32. Jaramillo DE, Arriola A, Safavi K, Chávez de Paz LE. Decreased bacterial adherence and biofilm growth on surfaces coated with a solution of benzalkonium chloride. J Endod. 2012 Jun;38(6):821-5. doi: 10.1016/j.joen.2012.03.012.

33. Baron A, Lindsey K, Sidow SJ, Dickinson D, Chuang A, McPherson JC 3rd. Effect of a Benzalkonium Chloride Surfactant-Sodium Hypochlorite Combination on Elimination of Enterococcus faecalis. J Endod. 2016 Jan;42(1):145-9. doi: 10.1016/j.joen.2015.08.035. 